\title{
DIE TOEPASLIKHEID VAN DEELTITELHEFFINGS IN SUID-AFRIKA
}

\author{
Christiaan Smit* \\ Noord-Wes Universiteit \\ Christiaan.smit@live.co.za \\ Merwe Oberholzer+ \\ Noord-Wes Universiteit \\ Merwe.Oberholzer @nwu.ac.za \\ Suria Ellis\# \\ Noord-Wes Universiteit \\ Suria.Ellis@nwu.ac.za
}

August 2011

\begin{abstract}
This study challenges the fairness of sectional title schemes' levies that are ordered by the Sectional Title Act (95 of 1986) to be allocated according to the participation quota (floor area) of units. Studies have shown that larger units in a sectional title scheme tend to subsidise the levies of smaller units. A log-transformed linear regression analysis was performed to investigate the cost behaviour of 113 sectional title schemes. The results revealed that $86 \%$ of the variation in the operating costs of a scheme is attributable to the variation in the area of a scheme, while $87 \%$ of the variation in operating costs is attributable to a variation in the number of units in a scheme. The conclusion is that the area and the number of units in a scheme are equally significant drivers of operating costs. Therefore, the study recommended that the levies should be allocated on a 50/50 basis with regard to area and number of units.
\end{abstract}

\section{Keywords}

Cost allocation, levies, operating costs, participation quota, Sectional Title Act

\footnotetext{
* Mr Christiaan Smit is a postgraduate student at the School of Accounting, North West University, Potchefstroom, South Africa. +Prof Merwe Oberholzer is a professor at the School of Accounting, North West University, Potchefstroom, South Africa. \#Dr Suria Ellis is Head: Statistical Consultation Services, North West University, Potchefstroom, South Africa
} 


\section{INLEIDING}

Hierdie studie handel oor die billikheid van die toedeling van heffings na elke eenheid in deeltitelkompleks volgens die deelnemingskwota. Volgens artikel 32 van die Wet op Deeltitels, 95 van 1986 word heffings toegedeel volgens die grootte oftewel die deelnemingskwota van 'n eenheid. Die deelnemingskwota is die vloeroppervlakte van 'n eenheid gedeel deur die totale vloeroppervlakte van al die eenhede (Constas \& Bleijs, 2009). Die heffings wat op grond van die deelnemingskwota bereken is, word gebruik om onder meer versekering, gemeenskaplike eiendom, elektrisiteit, water, hysbakonderhoud, ouditfooie, bestuursagentfooie, salarisse en lone, sekuriteit, swembaduitgawes en onderhoud vir die gebou te dek (Woudberg, 1999). Hierdie artikel ondersoek die billikheid van die voorskrif van die Wet met betrekking tot die berekening van elke eienaar se heffing in ' $n$ deeltitelkompleks op grond van sy/haar deelnemingskwota.

Daar is nog min navorsing gedoen rakende die billikheid om deelnemingskwotas as basis te gebruik vir die toedeling van heffings na deeltiteleenhede. Schutte (1995) het in studie onakkurate kosteberekening, wat tot onbillike heffings in deeltitelkomplekse lei, uitgewys. In sommige komplekse meen eienaars dat groter eenhede die kleiner eenhede subsidieer omdat die heffing op grond van die deelnemingskwota toegedeel word. Die voordele van 'n groter deelnemingskwota is dat 'n eienaar dan 'n groter stemreg op 'n vergadering het. Die vraag is of hierdie groter stemreg genoegsame kompensasie bied vir die hoër heffing. In die praktyk word ervaar dat daar by vergaderings in elk geval by wyse van hande opsteek gestem word en nie volgens die deelnemingskwota nie (Arnold, 2010). Verdere studies wat op die probleem van onbillikheid van deelnemingskwotas as toedelingsbasis fokus, is onder andere Maree (2001) en Woudberg (1999). Deur die deelnemingskwota alleen as toedelingsbasis te gebruik, beteken dat alle koste as afhanklik van die totale oppervlakte van die eenhede in kompleks beskou word. Dus word alle koste as veranderlik hanteer. Geen vaste koste word geïdentifiseer wat konstant is en nie afhanklik van die oppervlakte is nie. Die gaping wat in die literatuur bestaan, is dat daar nog beperkte kwantitatiewe empiriese navorsing gedoen is oor die billikheid van die huidige berekening van deeltitelheffings, die gedrag van die verskillende (indirekte) bedryfskoste-items en die uitwerking wat die aantal eenhede in 'n deeltitelkompleks op die koste het.

$\mathrm{Na}$ aanleiding van die probleem wat geïdentifiseer is, word die volgende navorsingsvrae gestel: Is dit billik dat deelnemingskwotas gebruik word om die heffings van deeltiteleenhede toe te deel? Wat behoort 'n sinvolle praktyk te wees om hierdie toedelings te doen?

Die doel van die studie is om die verwantskap tussen oppervlakte en bedryfskoste-items te bepaal. Die gedeelte van die koste wat deur oppervlakte veroorsaak word, behoort dan daarvolgens toegedeel te word. Verder is die doel ook om die verwantskap tussen die aantal eenhede in 'n kompleks en die bedryfskoste-items te bepaal. Die gedeelte van die koste wat deur die aantal eenhede veroorsaak word, behoort dan in eweredige dele na die eenhede toegedeel te word.

Die ontplooiing van die artikel is soos volg:

- Afdeling 2 verskaf voorbeelde waarom die bepalings van die Deeltitelwet ondersoek behoort te word.

- Afdeling 3 verduidelik relevante dele uit die Wet.

- Die navorsingsmetode word in afdeling 4 bespreek.

- Afdeling 5 toon die bevindings van die empiriese ondersoek en 
- gevolgtrekkings word in Afdeling 6 gemaak.

\section{AGTERGROND}

\subsection{Vorige navorsing}

Verskeie Suid-Afrikaanse studies is al gedoen met betrekking tot die Deeltitelwet, byvoorbeeld Brand (1999), Strydom (1997), Jonker (1988), Uys (1990) en Cloete (1982), maar hierdie studies het nie op die heffings gefokus nie. 'n Rekenaarsoektog van joernaalartikels oor die Deeltitelwet kon slegs die navorsing van Van der Merwe $(2009 ; 2010)$ opspoor, wat dan ook nie die billikheid van die heffings ondersoek nie.

Hierdie gedeelte bespreek verder kortliks bevindinge van vorige studies wat die billikheid van heffings ondersoek het. Woudberg (1999) wys daarop dat ontwikkelaars loodgieterkoste wil verminder deur net een watermeter te installeer om beide die gemeenskaplike eiendom se water en alle huishoudelike waterverbruik vir elke eenheid in die gebou te meet. Daar word nou wel gespaar deurdat daar nie individuele watermeters vir elke eenheid geïnstalleer word nie, maar individuele waterkoste moet nou na eienaars volgens die deelnemingskwotabasis toegedeel word. Bogenoemde word egter gesien as onbillik omdat 'n drieslaapkamerhuishouding met een of twee mense in alle waarskynlikheid minder water gebruik as 'n kleiner eenheid waar byvoorbeeld vier of vyf mense woon. Volgens Arnold (2010) is daar ook gevalle waar eienaars wat op die boonste verdieping woon, meen dat dit onbillik is dat hulle moet bydra tot water volgens die deelnemingskwota, want die eienaar wat op die grondverdieping woon het ' $n$ tuin wat gereeld natgespuit word.

Maree (2001) verwys na 'n gevallestudie waar die vraag gevra word of dit billik is dat eenvormige heffings vir hysbakke gehef word. In die gevallestudie bly die eienaar in 'n buurt wat uit 43 huise en twee blokke van 15 woonstelle elk bestaan. Elke blok is toegerus met 'n hysbak waarvan die onderhoud volgens die deelnemingskwota van alle eienaars verhaal moet word, insluitend die eienaars van losstaande huise. Die eienaars van die losstaande huise en grondverdiepingeenhede voel dat dit onbillik is dat hulle tot die hysbak moet bydra, aangesien hulle geen voordeel daaruit trek nie. Die wetgewer het egter spesiale melding gemaak van hysbakke in artikel $37(1)(j)$ (Wet op Deeltitels, 95 van 1986). Dit bepaal dat die regspersoon se pligte insluit om die gemeenskaplike eiendom (insluitend hysbakke) behoorlik te onderhou en dit in 'n goeie en bruikbare toestand in stand te hou. Die antwoord is dat die onderhoud van die hysbak nie aan eienaars wat dit gebruik alleenlik oorgelaat kan word nie. Die eienaars kan egter deur'n spesiale besluit bepaal dat nie-gebruikers se bydrae tot die onderhoud van die hysbak afgeskaal word. Daar moet egter skriftelike toestemming verkry word van enige eienaar wat finansieel daardeur benadeel word.

Schutte (1995) het in 'n studie die menings van bestuursagente en deeltiteleienaars met betrekking tot die kostegedrag van deeltitelkomplekse ingewin. Hierdie studie het getoon dat dit die mening is dat die gebruik van deelnemingskwotas as toedelingsbasis kleiner eenhede, ten koste van groter eenhede, bevoordeel. ' $n$ Aanbeveling is gedoen dat die aantal eenhede in 'n deeltitelkompleks as toedelingsbasis gebruik word, met ander woorde, elke eenheid dra 'n gelyke deel by om koste te verhaal. Dit is net so 'n onbillike toedelingsbasis as die huidige deelnemingskwotabasis, aangesien dit die teenoorgestelde uitwerking kan hê, naamlik dat kleiner eenhede in dié geval groter eenhede gaan subsidieer. 


\subsection{Kostegedrag}

Die volgende voorbeeld verduidelik die gevolg indien die gedrag van koste met betrekking tot kostedrywers geïgnoreer word. Aanvaar 'n deeltitelkompleks met slegs twee koste-items: Eerstens, versekeringspolis van Rl 000 per maand wat op die vervangingswaarde van elke $\mathrm{m}^{2}$ gebaseer is (aanvaar daar is geen gemeenskaplike eiendom nie). Tweedens, die bestuursagentskapsfooi van R1 000 per maand, met verantwoordelikhede om eiendomsbelasting van elke eienaar aan die munisipaliteit oor te betaal, die maandelikse versekering oor te betaal, sakelyste en notules van vergaderings vir elke eienaar voor te berei, ens. Die versekeringspolis is ' $n$ veranderlike koste met betrekking tot oppervlakte, aangesien dit in ' $n$ direkte verhouding sal verander indien die totale oppervlakte van die gebou sou verander (Horngren, Datar, Rajan, Ittner \& Foster, 2009). Die bestuursagentskapsfooi is ' $n$ vaste koste, met betrekking tot oppervlakte, aangesien dit konstant behoort te bly indien die totale oppervlakte van die gebou binne die relevante skaalwydte sou verander (Horngren et al., 2009). Drie verskillende scenario's word verduidelik (TABEL 1); waar die R2 000 toegedeel word op grond van oppervlakte $\left(\mathrm{m}^{2}\right)$, ' $\mathrm{n}$ eenheidsbasis en ' $\mathrm{n}$ 50/50 oppervlakte- en eenheidsbasis. Laasgenoemde is die enigste korrekte toedeling, aangesien dit die gedrag (oorsaak-gevolg) van koste in ag neem. Die volgende kan hieruit waargeneem word:

- Oppervlakte as toedelingsbasis bevoordeel die kleiner Eenhede 1 en 2, maar dit benadeel die groter Eenhede 4 en 5 . Gemeet aan die korrekte toedeling beteken dit dat Eenhede 1 en 2 onderskeidelik $33 \%$ en 14\% te min heffing betaal, terwyl Eenhede 4 en $5,11 \%$ en $20 \%$ onderskeidelik, te veel heffing betaal.

- Die toedelingsbasis per eenheid (waar alle koste gelykop tussen eenhede verdeel word) se uitwerking is presies die teenoorgestelde as wanneer die oppervlaktetoedelingsbasis gebruik word.

- Eenheid 3, waarvan die oppervlakte gelyk is aan die gemiddeld van al die eenhede, word nie deur die verskillende toedelingsbasisse beïnvloed nie.

TABEL 1: Voorbeeld van toedelingsbasisse en kostegedrag

\begin{tabular}{ccccccc}
\hline \multirow{2}{*}{ Eenheid } & Oppervlakte & \multicolumn{3}{c}{ Toedelingsbasis } & \multicolumn{2}{c}{ Oor-/onderbetaling } \\
& & Perm $m^{2}$ & Pereenheid & $50 / 50$ & Perm $^{2}$ & Pereenheid \\
\hline 1 & $\mathrm{~m}^{2}$ & $\mathrm{R}$ & $\mathrm{R}$ & $\mathrm{R}$ & & \\
2 & 50 & $200 *$ & $400 \star \star$ & $300 \star \star \star$ & $-33 \%$ & $33 \%$ \\
3 & 75 & 300 & 400 & 350 & $-14 \%$ & $14 \%$ \\
4 & 100 & 400 & 400 & 400 & $0 \%$ & $0 \%$ \\
5 & 125 & 500 & 400 & 450 & $11 \%$ & $-11 \%$ \\
& $\underline{150}$ & $\underline{600}$ & $\underline{400}$ & $\underline{\underline{500}}$ & $20 \%$ & $-20 \%$ \\
\hline$\underline{\underline{200}}$ & $\underline{\underline{2000}}$ & $\underline{\underline{2000}}$ & $\underline{\underline{2000}}$ & & \\
\hline
\end{tabular}

Bron: Eie berekeninge

$\star 50 / 500 \times \mathrm{R} 2000=\mathrm{R} 200 ; * \star \mathrm{R} 2000 / 5=\mathrm{R} 400 ; * \star \star(50 \% \times 50 / 500 \times \mathrm{R} 2000)+(50 \% \times \mathrm{R} 2000 / 5)$

Die sentrale hoofargument van hierdie studie is dat die Deeltitelwet onbillik is deurdat die deelnemingskwota alleen as toedelingsbasis gebruik word wat die gevolg het dat groter eenhede kleiner eenhede subsidieer. Indien deelnemingskwotas wel gebruik word, word dit nie betwyfel 
dat die oppervlakte van ' $n$ eenheid ' $n$ belangrike kostedrywer is nie, maar die toedeling behoort nie lineêr gedoen te word nie, aangesien die skaalbesparings van die groter eenheid heeltemal geïgnoreer word.

\section{TEORIE}

\subsection{Basiese begrippe van die Deeltitelwet}

Artikel 36 van die Deeltitelwet handel oor die regspersoon wat bestaan uit al die eienaars van eenhede in 'n kompleks. Die oomblik wat 'n eenheid in die eienaar se naam geregistreer word, word die eienaar deel van die regspersoon. Die regspersoon het die vermoë om te kontrakteer, te dagvaar en gedagvaar te word (Constas \& Bleijs, 2009).

' $n$ Eenheid is elke eienaar se deel plus die eienaar se aandeel in die gemeenskaplike eiendom. Elke eienaar wat ' $n$ deel besit, besit outomaties ook 'n aandeel in die gemeenskaplike eiendom. Die deel en die aandeel in gemeenskaplike eiendom is 'n eenheid (Paddock, 2008). Die gemeenskaplike eiendom sluit in die grond, deurgange, parkeerareas, mure, hekke, die area tussen die dak en die mediaanlyne van die plafon en die buitekant van die gebou, insluitend die dak en fondasies. Gemeenskaplike eiendom word besit deur alle eienaars in die skema in onverdeelde aandele. Dit beteken dat elke eienaar outomaties 'n aandeel het in die grond en die area wat niemand spesifiek se deel is nie. Die gemeenskaplike eiendom word altyd deur die regspersoon (Constas \& Bleijs, 2009) beheer .

Die deelnemingskwota is 'n persentasie wat die aandeel in die gemeenskaplike eiendom omskryf wat aan elke deel toegeken word. Die deelnemingskwota (afgerond tot vier desimale plekke) vir elke deel word bepaal deur die vloeroppervlakte van 'n betrokke deel in verhouding tot die totale vloeroppervlakte van al die dele in die kompleks (Paddock, 2008). Volgens Constas en Bleijs (2009) is die belangrikheid van die deelnemingskwota soos volg:

Dit word gebruik om die finansiële bydrae van elke eienaar uit te werk. Dit sluit heffings, die gedeelte van 'n eienaar se skuld, in 'n geval waar die regspersoon 'n ander eienaar geld skuld, en spesiale heffings in. Dit word gebruik om die gewig van 'n eienaar se stem uit te werk waar stemme op 'n algemene jaarvergadering volgens die deelnemingskwota uitgebring word. Dit word ook gebruik om die onverdeelde deel van die gemeenskaplike eiendom vir elke eienaar uit te werk.

\subsection{Gemeenskaplike eiendom en uitsluitlike gebruikersarea}

Dit is die plig van die regspersoon om die gemeenskaplike eiendom ten alle tye in 'n goeie en bruikbare toestand te hou. Die onderhoud van gemeenskaplike eiendom sluit ook alle uitsluitlike gebruikersgebiede in, aangesien dit ook gemeenskaplike eiendom is.

By balkonne, patio's, stoepe en motorhuise is dit belangrik dat die trustees weet wat die status van die dele is. Dit kan vanuit die deelplan verkry word. Indien die balkon by 'n deel ingesluit is, is die deelnemingskwota van daardie deel reeds bereken en betaal die eienaar dus klaar 'n heffing daarop. Eienaars met buitengewoon groot balkonne voel dikwels ongelukkig hieroor, aangesien hulle nou heelwat meer vir heffing moet betaal en nie regtig 'n gelykwaardige voordeel daaruit kry nie. Indien die stoep of balkon gemeenskaplike eiendom is, mag die trustees geen heffing daarop vasstel nie (Maree, 2001). As die stoep of balkon 'n uitsluitlike 
gebruikersgebied is, moet die trustees ' $n$ addisionele bedrag daarop bereken. Volgens Paddock (2009) bepaal artikel 37(1)(b) van die Deeltitelwet dat die regspersoon nie 'n heffing mag hef op 'n uitsluitlike gebruikersgebied nie. Die regspersoon is slegs geregtig om die eienaar' $n$ bedrag te vra wat geag nodig sal wees om die koste van tariewe, versekering en instandhouding ten opsigte van sodanige gedeelte te dek. In die praktyk word egter dikwels 'n vaste bedrag gehef vir 'n uitsluitlike gebruikersgebied ongeag die bedrag wat werklik op die uitsluitlike gebruikersgebied spandeer word.

\subsection{Toedeling van heffings na eenhede}

Volgens artikel 32 van die Deeltitelwet word heffings toegedeel na eenhede volgens die deelnemingskwota van elke deel. Dit beteken dat hoe groter die deel is hoe meer heffing gaan die eienaar van die eenheid betaal (Constas \& Bleijs, 2009). Heffings kan slegs verhaal word van die eienaars wat op daardie stadium geregistreerde eienaars is. Artikel 37(2) verplig eienaars om heffings te betaal en vir trustees om stappe te doen teen eienaars wat nie die heffing betaal nie (Maree, 2001). Trustees moet ' $n$ begroting opstel vir die verwagte inkomste en uitgawes vir die volgende finansiële jaar. Tydens die algemene jaarvergadering moet eienaars die begroting met of sonder wysigings goedkeur. As eienaars die begroting goedkeur, beteken dit dus dat elke eienaar outomaties die totale heffings vir die komende jaar van die eienaars bepaal (Maree, 2001).

\subsection{Verandering aan die formule om heffings te bepaal}

Alle heffings moet volgens artikel 32(3)(c) van die Deeltitelwet volgens die deelnemingskwota bereken word. Daar is egter uitsonderings waar die heffing nie volgens deelnemingskwotas bereken word nie. Dit is wanneer daar 'n alternatiewe wyse van berekening vir heffings is en in die geval van uitsluitlike gebruikersgebiede. Die bevoegdheid om die formule vir heffings te verander, berus by die ontwikkelaar en, na die totstandkoming van die regspersoon, by die regspersoon. Die enigste wyse waarvolgens 'n wysiging aangebring kan word, is wanneer die bestuursreëls gewysig word. Gewoonlik kan bestuursreëls net deur middel van 'n eenparige besluit gewysig word. In dié geval kan die wysiging egter deur 'n spesiale besluit bepaal word, mits die skriftelike toestemming van alle eienaars verkry word wat deur die wysiging benadeel word (Maree, 200).

\section{METODE}

\subsection{Steekproef en data}

Data vir hierdie studie is vanaf die ANGOR Property Specialists (Pty) Ltd databasis verkry. Die databasis bevat 211 komplekse en die grootste deel daarvan is in Johannesburg se noordelike en noord-westelike voorstede. Daar is egter ook komplekse in Pretoria, Ramsgate, Vereeniging en Vanderbijlpark. Met'n sistematiese steekproefneming is 102 komplekse in totaal gekies. Nog 13 komplekse waarvan die oppervlakte tussen $10000 \mathrm{~m}^{2}$ en $25000 \mathrm{~m}^{2}$ is, is deur middel van 'n niewaarskynlikheidsteekproef gekies. Die komplekse is so gekies sodat party komplekse klein oppervlaktes het en ander komplekse groot oppervlaktes het om sodoende so 'n groot as moontlike spreiding van data te kry om 'n goeie regressie-passing te kan doen. Die rede hiervoor is dat daar nie sekerheid is dat die kostestrukture van groot en klein komplekse dieselfde is nie. Die regressie-afsnit is baie belangrik om vaste koste te kan bepaal en daar is ook spesifiek 
gepoog om verskeie klein komplekse te kry sodat daar so na as moontlik aan nul gekom kan word om die afstand waarin na nul geëkstrapoleer moet word om 'n afsnit te kry so klein as moontlik te maak. Met ander woorde, om die afsnit so interpreteerbaar as moontlik te maak.

Projekte is uitgehaal as 'n koste-item, aangesien nie al die komplekse elke jaar projekte het nie en dit moontlik dan 'n uitskieter sal wees. Elektrisiteit van eenhede is ook uit die koste-items verwyder, aangesien dit nie verband met die heffing hou nie en direk na elke eenheid nagespeur kan word. Gemeenskaplike eiendomselektrisiteit beïnvloed egter wel die heffing, maar aangesien elektrisiteit en gemeenskaplike eiendomselektrisiteit gesamentlik in die data verskyn, is dit nie moontlik om gemeenskaplike eiendomselektrisiteit te identifiseer nie. Uit die steekproef is daar egter wel 25 komplekse wat watermeters vir elke eenheid het, maar water is hanteer asof dit gemeenskaplike koste vir al die eenhede is. Dit is net om met meer data die gedrag van water as koste-item te bepaal indien dit nie direk na elke eenheid nagespeur sou word nie. Uit die 115 komplekse is die grootste twee komplekse met oppervlaktes van onderskeidelik $46686 \mathrm{~m}^{2}$ en $53379 \mathrm{~m}^{2}$ nie in berekening gebring nie om seker te maak dat daar nie in die regressie ' $n$ hefboomeffek bewerkstellig is deur die twee groot datapunte in die regressie nie. Dit laat dus 'n steekproef van 113 komplekse met 'n totale oppervlakte van tussen $704 \mathrm{~m}^{2}$ en $27579 \mathrm{~m}^{2}$ waarvan die data ontleed is.

Werklike koste vir die jaar geëindig in 2010 van die 113 komplekse is gebruik. Alhoewel dit 'n relatief lae-inflasie-tydperk was, is die effek van inflasie steeds verskans om alle koste met behulp van die verbruikersprysindeks tot Desember 2010 te verdiskonteer.

\subsection{Bedryfskoste}

Heffing in deeltitelkomplekse word aangewend om die bedryfskoste daarvan te betaal. In hierdie studie is die bedryfskoste onder die volgende groepe ingedeel (dit is in volgorde van persentasie van totale koste, soos empiries bepaal, gerangskik):

- Sekuriteit (22.44\%)

- Onderhoud en herstelwerk (19.05\%)

- Bestuursuitgawes (17.25\%)

- Riolering (12.32\%)

- Tuin- en swembaduitgawes $(8.5 \%)$

- Water (8.39\%)

- Versekering (7.49\%)

- Vullis (2.5\%) (Dit sluit nie die munisipale diens van vullisverwydering in nie.)

- Ander uitgawes (1.12\%)

- Professionele fooie $(0.94 \%)$

\subsection{Statistiese ontleding}

Eerstens sal beskrywende statistiek gebruik word om totale koste te ontleed. Verder word ontledings gedoen met behulp van eenvoudige lineêre regressie-ontleding, waar die oppervlakte en die aantal eenhede om die beurt die onafhanklike veranderlikes $(x)$ is, met bedryfskoste as die afhanklike veranderlike (y). Meervoudige lineêre regressie-ontleding is nie oorweeg nie, waar beide oppervlakte en aantal eenhede die onafhanklike veranderlikes is, want die korrelasie tussen hierdie twee veranderlikes is baie sterk $(r=0.91$ - Microsoft Excel berekening) wat tot 
gevolg het dat totale oppervlakte en aantal eenhede kollineêre veranderlikes is en nie saam in 'n regressie-analise vir voorspelling gebruik kan word nie.

Indien 'n kontroversiële lineêre verband tussen $x$ en $y$ gevind word, kan 'n lineêre verwantskap tussen $\log x$ en log $y$ ondersoek word. Dan is die magskromme $\hat{y}=a x^{b}$ 'n geskikte kromme om die verwantskap tussen $x$ en $y$ te beskryf. Die vergelyking kan in logaritmiese vorm geskryf word as:

$$
\log \hat{y}=\log a+b \log x
$$

As $y^{\prime}, a^{\prime}$ en $x^{\prime}$ onderskeidelik $\log \hat{y}, \log a$ en $\log x$ aandui, dan word die vergelyking van 'n reguitlyn verkry:

$$
y^{\prime}=a^{\prime}+b x^{\prime}
$$

met afsnit $a$ ' en helling $b$ (Steyn et al., 1999).

'n Hipotesetoetsing is ook gedoen. Die nulhipotese wat aangedui word deur $\mathrm{H}_{0}$ is 'n bewering aangaande die waarde van die populasiemeter. Die waarde is die heersende waarde wat voorlopig as korrek aanvaar word, totdat dit verkeerd bewys word. Die alternatiewe hipotese wat aangedui word deur Ha spesifiseer vir die populasieparameter 'n versameling waardes wat nie deur die nulhipotese gespesifiseer is nie (Allison, Swanepoel, Swanepoel, Santana, Weideman \& Van Graan, 2005). By die tweekantige alternatiewe hipotese word beweer dat die populasieparameter nie gelyk is aan die beweerde waarde onder $\mathrm{H}_{0}$ nie.

- $\mathrm{H}_{0}$ : regressie-afsnit $=0$

- $H_{a}$ : regressie-afsnit $\neq 0$.

- $\mathrm{H}_{0}$ : regressiehelling $=0$

- $H_{a}$ : regressiehelling $\neq 0$.

Die $\mathrm{H}_{0}$ word op die volgende beduidendheidsvlakke gemeet, naamlik een persent en vyf persent (tweekantig), waar $p<a$ en waar $a=.01$ en .05 , respektiewelik. Waar $p$-waarde $>.05$ is, kan aanvaar word dat daar geen bewys van 'n statisties betekenisvolle afsnit of helling is nie, met ander woorde die afsnit of helling kon net sowel nul gewees het (Wegner, 2007). 


\section{BEVINDINGS}

\subsection{Totale koste}

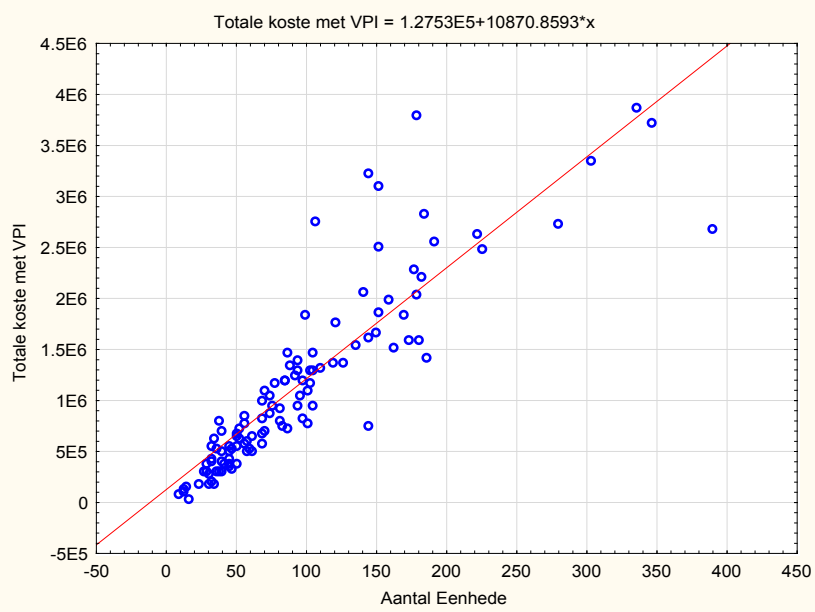

\section{FIGUUR 1: Spreidingsdiagram: Totale koste teenoor aantal eenhede}

\section{Bron: Ontleding van steekproefdata}

In FIGUUR $\mathbf{I}$ is die heteroskedastisiteit van die variansies duidelik, waar die spreiding baie groter is by groter waardes van 'n aantal eenhede as by kleiner waardes, wat 'n log-transformasie noodsaaklik maak om die variansie in die data te stabiliseer. 'n Magskromme het hier geblyk die beste transformasie te wees vir beide homoskedastisiteit van variansies en normaliteit van die residu van die passing.

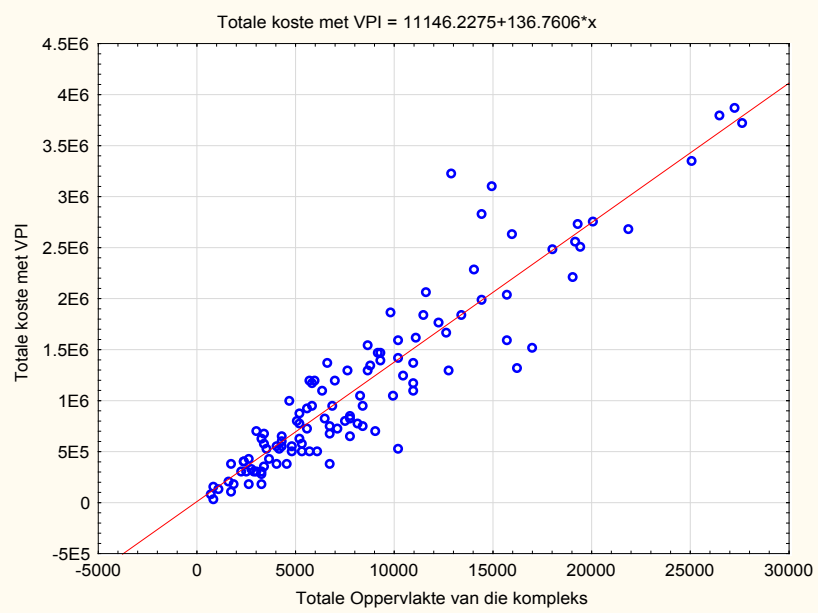

FIGUUR 2: Spreidingsdiagram: Totale koste teenoor totale oppervlakte van kompleks

Bron: Ontleding van steekproefdata

In bogenoemde spreidingsdiagram (FIGUUR 2) is die spreiding ook meer by groter oppervlaktes 
as by kleiner oppervlaktes, wat dui op heteroskedastisiteit van die variansies en dus 'n logtransformasie noodsaak. 'n Magskromme het dus ook geblyk die beste transformasie te wees vir beide homoskedastisiteit van variansies en normaliteit van die residu van die passing.

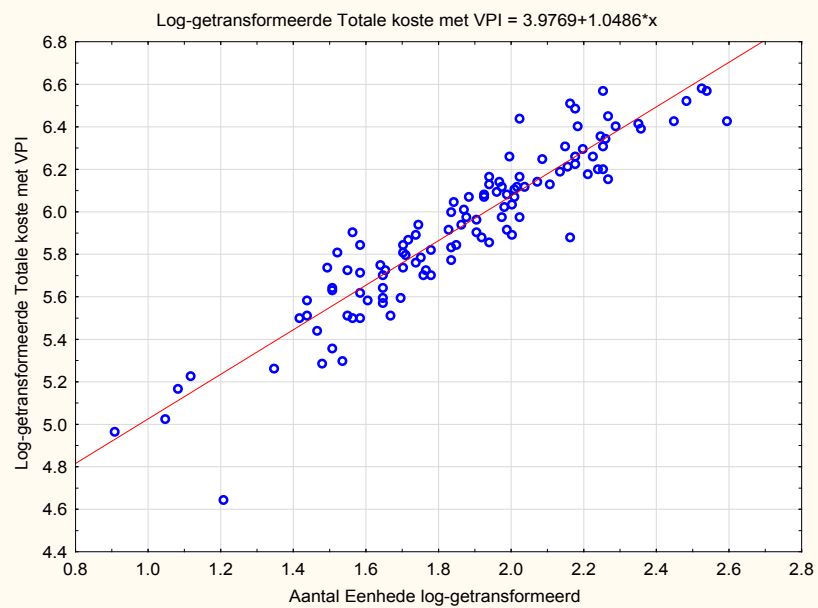

FIGUUR 3: Spreidingsdiagram: Totale koste teenoor eenhede(log-getransformeerd)

Bron: Ontleding van steekproefdata

In bogenoemde spreidingsdiagram (FIGUUR 3) is 'n meer homogene spreading in variansies sigbaar.

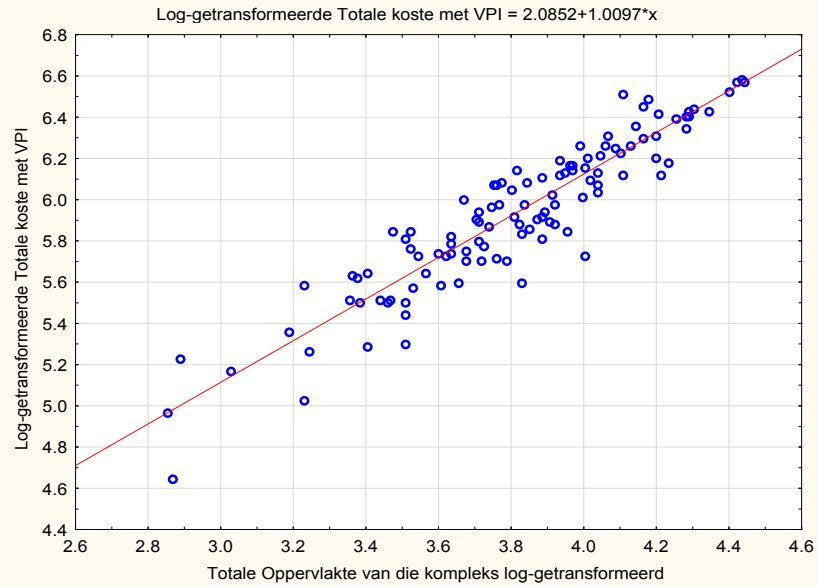

FIGUUR 4: Spreidingsdiagram: Totale koste teenoor totale oppervlakte van kompleks (loggetransformeerd)

Bron: Ontleding van steekproefdata

In bogenoemde spreidingsdiagram (FIGUUR 4) is ook 'n meer homogene spreiding in variansies sigbaar.

In TABEL 2 toon die beskrywende statistiek vir totale koste dat dit vir 'n kompleks in die steekproef varieer tussen R44 287 en R3 893 468. Die mediaan is R872 997 wat heelwat kleiner is as die rekeningkundige gemiddeld van Rl 160843 , wat daarop dui dat daar 'n paar komplekse is 
met heelwat groter koste as die res van die komplekse; die verdeling is dus skeef na regs. Op grond van die beskrywende statistiek en die voorafgaande figure is dit duidelik dat die effek van nie-normaliteit van die afhanklike veranderlike sowel as die heteroskedastisiteit van die variansies dus van die magskromme 'n meer sinvolle ontleding maak.

TABEL 2: Totale koste: beskrywende statistiek en regressie- en korrelasie-ontleding

\begin{tabular}{|c|c|c|c|c|}
\hline \multicolumn{5}{|c|}{ Beskrywende statistiek } \\
\hline Gemiddeld & & & & 1160843 \\
\hline Mediaan & & & & 872997 \\
\hline Minimum & & & & 44287 \\
\hline Maksimum & & & & 3893468 \\
\hline \multicolumn{5}{|c|}{ Regressie- en korrelasie-ontleding: $x=$ aantal eenhede, $y=$ totale koste } \\
\hline $\mathrm{R}$ & & & & 0,93 \\
\hline $\mathrm{R}^{2}$ & & & & 0,87 \\
\hline Aangepaste $\mathrm{R}^{2}$ & & & & 0,87 \\
\hline \multirow[t]{2}{*}{ Observasies } & & & & 113 \\
\hline & Koëffisiënte* & Standaardfout* & $t$-waarde & p-waarde \\
\hline Afsnit & 9482 & 1,18 & 54,01 & $<0,001$ \\
\hline $\mathrm{x}$ veranderlike & 1,05 & 0,04 & 26,94 & $<0,001$ \\
\hline \multicolumn{5}{|c|}{ Regressie- en korrelasie-ontleding: $x=$ oppervlakte, $y=$ totale koste } \\
\hline $\mathrm{R}$ & & & & 0,93 \\
\hline $\mathrm{R}^{2}$ & & & & 0,86 \\
\hline Aangepaste $\mathrm{R}^{2}$ & & & & 0,86 \\
\hline \multirow[t]{2}{*}{ Observasies } & & & & 113 \\
\hline & Koëffisiënte* & Standaardfout* & $t$-waarde & p-waarde \\
\hline Afsnit & 122 & 1,40 & 14,39 & $<0,001$ \\
\hline$x$ veranderlike & 1,01 & 0,04 & 26,64 & $<0,001$ \\
\hline
\end{tabular}

Bron: Ontleding van steekproefdata

*Getransformeerde afsnit

Dataverwerkings met $\log 10$-getransformeerde data is gebruik om nie-normaliteit in data te korrigeer. TABEL 2 toon die magskromme se regressie-statistiek, eerstens vir totale koste (bedryfskoste) teenoor aantal eenhede en tweedens teenoor totale oppervlakte van ' $n$ kompleks. Die bepaaldheidskoëffisiënte $\left(R^{2}\right)$ impliseer dat $87 \%$ en $86 \%$ van die variansie in totale koste deur die variansie in die aantal eenhede in 'n kompleks en deur die variansie in totale oppervlakte van 'n kompleks, onderskeidelik verklaar kan word. Die $p$-waarde is in albei gevalle vir beide die afsnit en die helling kleiner as 0,001 . Hieruit kan afgelei word dat beide die helling en afsnit statisties betekenisvol is op 'n een-persent-peil van betekenis. In albei die gevalle van helling en afsnit kan die nulhipotese dus verwerp word. Waar $x=$ aantal eenhede, dui die resultaat daarop dat daar 'n koste van R9 482 per jaar is wat as vaste koste beskou kan word. Waar $x$ = oppervlakte van 'n kompleks, dui die resultaat daarop dat daar koste van R122 per jaar is wat as vaste koste beskou kan word. Hierdie bedrag is egter so klein dat dit nie in die praktyk sinvol sal wees nie. 


\subsection{Individuele koste-items}

Soortgelyke figure, soos FIGUUR 1 en FIGUUR 2, is vir elkeen van die koste-items opgestel om saam met die beskrywende statistiek die data ook visueel te beoordeel. As gevolg van beperkte ruimte word hierdie figure nie getoon nie. Net soos in die geval van totale koste is bevind dat die nie-normaliteit van die afhanklike veranderlike sowel as die heteroskedastisiteit van die variansies van die magskromme 'n meer sinvolle ontleding maak. TABEL 3 voorsien opsomming van totale koste en individuele koste-items waar $x$ die aantal eenhede en totale oppervlakte onderskeidelik verteenwoordig. Die nulhipotese-toetsing, met behulp van die $p$-waarde, word telkens getoon.

TABEL 3: Magskromme se $\boldsymbol{p}$-waardes vir afsnit en helling

\begin{tabular}{|c|c|c|c|c|}
\hline \multirow[t]{2}{*}{$y$} & \multicolumn{2}{|c|}{$x=$ Aantal eenhede } & \multicolumn{2}{|c|}{$x=$ Totale oppervlakte } \\
\hline & p-waarde afsnit & $\begin{array}{c}p \text {-waarde } \\
\text { helling }\end{array}$ & p-waarde afsnit & $\begin{array}{c}p \text {-waarde } \\
\text { helling }\end{array}$ \\
\hline Totale koste & $<0,001 * \star \star$ & $<0,001 * \star \star$ & $<0,001 * \star \star$ & $<0,001 * \star \star$ \\
\hline Sekuriteit & $<0,001 * \star \star$ & $<0,00 l^{\star \star \star \star}$ & 0,3540 & $<0,001 * \star \star$ \\
\hline Onderhoud en herstel & $<0,001 \star \star \star \star$ & $<0,001 * \star \star$ & $0,0138 * \star$ & $<0,001 * \star \star$ \\
\hline Bestuursuitgawes & $<0,001 * \star \star$ & $<0,001^{\star \star \star \star}$ & $<0,001 * \star \star$ & $<0,001 * \star \star$ \\
\hline Riolering & $<0,001 \star \star \star \star$ & $<0,001 * \star \star$ & $<0,001 \star \star \star \star$ & $<0,001 * \star \star$ \\
\hline $\begin{array}{l}\text { Tuin- en } \\
\text { swembaduitgawes }\end{array}$ & $<0,001 \star \star \star$ & $<0,001^{\star \star \star \star}$ & 0,8369 & $<0,001 * \star \star$ \\
\hline Water & $<0,001 \star \star \star \star$ & $<0,001 * \star \star$ & $<0,001 \star \star \star \star$ & $<0,001 \star \star \star \star$ \\
\hline Versekering & $<0,001 * \star \star$ & $<0,001^{\star \star \star \star}$ & $<0,001 * \star \star$ & $<0,001 * \star \star$ \\
\hline Vullis & $<0,013 \star \star \star$ & $<0,001 \star \star \star \star$ & 0,8501 & $<0,001 * \star \star$ \\
\hline Ander uitgawes & $<0,001 * \star \star$ & $<0,001^{\star \star \star \star}$ & $0,0137 * \star$ & $<0,001 * \star \star$ \\
\hline Professionele fooie* & $<0,001 \star \star \star \star$ & 0,0695 & $<0,001 \star \star \star \star$ & 0,0548 \\
\hline
\end{tabular}

Bron: Ontleding van steekproefdata

* Regressie was nie sinvol nie, omdat slegs $3 \%$ van die variansie verklaar is.

$\star \star$ Statisties betekenisvol by $5 \%$ (tweekantig).

$\star \star \star$ Statisties betekenisvol by $1 \%$ (tweekantig).

Die vaste koste (afsnit) is ook bereken en word in TABEL $\mathbf{4}$ saamgevat (waar die randwaardes die vaste koste per jaar voorstel).

Die oogmerk om veranderlike koste te identifiseer, is om te bepaal in watter mate die koste verander indien $x$ verander. TABEL 3 toon dat die nulhipotese met betrekking tot die helling vir totale koste en ook vir elke individuele koste-item in al die gevalle verwerp is (dus, waar $x=$ eenhede en waar $x=$ oppervlakte), buiten vir professionele fooie, wat in elk geval net $0,94 \%$ van die totale koste uitmaak. Hierdie regressie-ontleding toon dus 'n baie sterk positiewe verwantskap tussen die aantal eenhede en koste, asook 'n baie sterk positiewe verwantskap tussen oppervlakte en koste. 
TABEL 4: Vaste koste waar $x=$ eenhede en waar $x=$ oppervlakte

\begin{tabular}{lcc}
\hline \multicolumn{1}{c}{ Koste-item } & Vaste koste $(x=$ eenhede $)$ & Vaste koste $(x=$ oppervlakte $)$ \\
& $(R)$ & $(R)$ \\
\hline Totale koste & 9432 & 122 \\
Sekuriteit & 157 & 0 \\
Onderhoud en herstelwerk & 1150 & 7 \\
Bestuursuitgawes & 2427 & 58 \\
Riolering & 927 & 2 \\
Tuin- en swembaduitgawes & 156 & 0 \\
Water & 1794 & 43 \\
Versekering & 1211 & 15 \\
Vullis & 58 & 0 \\
Ander uitgawes & 28 & 0 \\
Professionele fooie & 8737 & 8737 \\
\hline
\end{tabular}

\section{Bron: Ontleding van steekproefdata}

Die oogmerk om vaste koste te identifiseer is dat dit tussen alle eenhede in 'n kompleks gelykop verdeel moet word. Die vaste koste word in TABEL 4 getoon waar die randwaarde gegee word indien die nulhipotese met betrekking tot die afsnit verwerp is (TABEL 3). Die jaarlikse vaste koste is deurgaans hoër waar $x$ = aantal eenhede as in die geval waar $x=$ oppervlakte van die kompleks. Al die waardes waar $x=$ oppervlakte van 'n kompleks, is in die praktyk te klein om enigsins sinvol te wees. Waar $x$ = aantal eenhede beteken die afsnit vaste koste ongeag die aantal eenhede wat daar is. Die vaste koste van items soos sekuriteit (R157), tuin- en swembaduitgawes (R156), vullis (R58) en ander uitgawes (R28) is ook te klein om prakties sinvol gebruik te word. Die res van die bedrae blyk ook nie juis prakties sinvol vir die meeste komplekse te wees nie indien dit in perspektief gestel word deur dit te vergelyk met die beskrywende statistiek soos in TABEL 2, waar 'n kompleks se totale koste tot so min as R44 287 is en vir 'n ander tot so hoog as R3 893468 is, met'n mediaan van R872 997.

\section{GEVOLGTREKKING}

In hierdie studie is die kostegedrag van 'n steekproef van 113 deeltitelkomplekse ontleed. Die nie-normaliteit van die afhanklike veranderlike sowel as die heteroskedastisiteit van die variansies het van die magskromme 'n meer sinvolle ontleding gemaak, en regressie- en korrelasie-ontleding is in hierdie verband gedoen. Die beperkings van die studie is dat projekte as 'n koste-item nie ontleed is nie en koste van gemeenskaplike elektrisiteit is ook uitgesluit. Slegs die oppervlakte en aantal eenhede is as onafhanklike veranderlikes ondersoek. Ander kostedrywers kan ook in ag geneem word, byvoorbeeld waar elke eenheid nie 'n eie watermeter het nie, kan dit ook sinvolle praktyk wees om water $(8,39 \%)$ volgens die aantal persone in 'n eenheid of volgens elektrisiteitsverbruik van die eenheid toe te deel.

Die navorsingsvraag bevraagteken die billikheid van die deelnemingskwota as kostedrywer vir die heffingsbedrag van eenhede. $0 \mathrm{~m}$ dit te beantwoord was dit nodig om die gedrag van koste te ondersoek. Met die ontleding van die afsnit is bevind dat waar $x$ = oppervlakte van 'n kompleks, is vaste koste, waar dit wel betekenisvol is, in die praktyk te klein om enigsins sinvol te wees. 
Waar $x$ = aantal eenhede, is die vaste koste meestal ook te klein om prakties sinvol te wees. Waar dit wel sinvol is, behoort dit eweredig tussen al die eenhede verdeel te word. Die res van die koste word dan ook per eenheid toegedeel, wat beteken dat dit sinloos is om koste in vaste en veranderlike komponente te skei indien $x=$ aantal eenhede. Die studie het bevind dat die nulhipotese met betrekking tot die helling vir totale koste en ook vir elke individuele koste-item in al die gevalle verwerp is (dus, waar $x=$ eenhede en waar $x=$ oppervlakte), buiten vir professionele fooie, wat in elk geval net $0,94 \%$ van die totale koste uitmaak (TABEL 3). Dit is ' $n$ bewys van ' $n$ baie sterk verwantskap tussen koste en beide eenhede en oppervlakte.

Indien die kwessie ook uit die hoek van totale koste beskou word, is bevind dat $86 \%$ (bepaaldheidskoëffisiënt) van die variansie in totale koste deur die variansie in die totale oppervlakte in 'n kompleks verklaar kan word, terwyl die bepaaldheidskoëffisiënt toon dat $87 \%$ van die variansie in totale koste deur die variansie in die aantal eenhede in 'n kompleks verklaar kan word. Vanuit die statistiese ontledings word dus afgelei dat dit om 't ewe is of deelnemingskwota of die aantal eenhede as onafhanklike veranderlike gebruik word, waaruit dan weer afgelei kan word dat deur slegs die deelnemingskwotas as toedelingsbasis te gebruik nie billik is nie, want die aandeel wat die aantal eenhede in die generering van bedryfskoste speel, kan nie net geïgnoreer word nie.

In die navorsingsvraag word ook gevra wat behoort sinvolle praktyk te wees om hierdie toedelings te doen. Met die wete dat met die gebruik van deelnemingskwotas kleiner eenhede ten koste van groter eenhede gesubsidieer word, en met die gebruik van eenhede groter eenhede ten koste van kleiner eenhede gesubsidieer word (TABEL 1), kom die studie tot die slotsom dat die antwoord op hierdie brandpunt is om ' $n$ kombinasie van hierdie twee kostedrywers te gebruik.

Let weer daarop dat die toedeling van gemeenskaplike bedryfskoste van 'n kompleks slegs 'n brandpunt is sodra daar variansie in die oppervlakte van die eenhede is. Waar al die eenhede in 'n kompleks min of meer dieselfde oppervlakte het, sal dit nie 'n groot verskil maak indien die deelnemingskwota, eenhede, of watter kombinasie ook al hiervan, as toedelingsbasis gebruik word nie (TABEL 1). Indien daar variansie in die oppervlakte van eenhede binne 'n kompleks bestaan, is die enigste billike oplossing om 'n kombinasie van die aantal eenhede en deelnemingskwota as toedelingsbasis te gebruik. Hierdie studie beveel aan dat dit, op grond van billikheid en eenvoud, op 'n 50/50-grondslag gebruik word.

Die praktiese implikasie van die studie is ook dat die Wet te rigied is en verander behoort te word. $0 \mathrm{~m}$ die heffing op 'n 50/50-eenhede en oppervlakte-basis toe te deel, is 'n riglyn wat verfyn kan word na aanleiding van komplekse se unieke omstandighede. Die bydrae van die studie is dat dit empiries die gedrag van koste-items bepaal het om sodoende meer akkurate toedelings van bedryfskoste te doen. Dit sal tot groter billikheid lei en kruissubsidiëring van eenhede in 'n groot mate uitskakel. Die studie is ook die eerste kwantitatiewe empiriese studie wat oor dié onderwerp in Suid-Afrika gedoen is. Verdere navorsing kan gedoen word om te bepaal hoe verskillende lande se deeltitelwette die bepaling van heffings bereken.

\section{VeRWYSINGSLYS}

Allison, J.S., Swanepoel, J.W.H., Swanepoel, C.J., Santana, L., Weideman, H.M. \& Van Graan, F.C. (2005). Inleidende statistiek vir die Ekonomiese Wetenskappe. Potchefstroom: The Platinum Press. 
Arnold, P.H. (2010). Bestuurder - Property Management, Angor Property Specialists (Pty) Ltd. 2010. Mondelinge mededeling aan outeur. Johannesburg.

Brand, A. (1999). Die belastinghantering van deeltitel-, aandeleblok-, en eiendomstyd-deelskemas. Ongepubliseerde MCom-verhandeling. Johannesburg: Randse Afrikaanse Universiteit.

Cloete, C.E. (1982). Die beleggingspotensiaal van residensiële deeltitelontwikkelings in die oostelike voorstede van Pretoria. Ongepubliseerde MBL-verhandeling. Pretoria: Universiteit van Suid-Afrika.

Constas, M. \& Bleijs, K. (2009). Demystifying sectional title, $2^{\text {nd }}$ edition. South Africa: BBM Publishing.

Horngren, C.T., Datar, S.M., Foster, G., Rajan, M. \& Ittner, C. (2009) Cost accounting: A managerial emphasis, $12^{\text {th }}$ edition. N.J.: Pearson / Prentice-Hall.

Jonker, M.A. (1988). Deeltitel-, aandeleblok-, en okkupasieskemas as juridiese raamwerke vir aftreeoorde. Ongepubliseerde LLM-verhandeling. Johannesburg: Randse Afrikaanse Universiteit.

Maree, T. (2001). Kitsdeeltiteloplossings. Stellenbosch: MCS Publications.

Paddock, G.J. (2008). Sectional title survival manual. Cape Town: Paddocks Publishing.

Paddock, J. (2009). Q \& A with Jennifer. Paddocks Press, 4(5), pp. 1-11.

Schutte, M. (1995). Kostegedrag en skeiding aan die hand van bepaling van heffingskoste by'n deeltitelkompleks. MCom-verhandeling. Johannesburg: Vista Universiteit.

Suid-Afrika. (2002). Wet op Deeltitels 95 van 1986. Durban: Butterworths.

Steyn, A.G.W., Smit, C.F., Du Toit, S.H.C. \& Strasheim, C. (1999). Moderne statistiek vir die praktyk, $5^{\text {de }}$ uitgawe. Pretoria: Van Schaik.

Strydom, J.J. (1997). Regsaspekte van die bestuur van 'n deeltitelskema. LLD-tesis. Stellenbosch: Stellenbosch Universiteit.

Uys, M. (1990). Voorstelle ter verbetering van die steeds onbevredigende posisie van sakedeeleienaars onder die Wet op Deeltitels, 1986. LLM verhandeling. Stellenbosch: Stellenbosch Universiteit.

Van der Merwe, C.G. (2009). Review of the recent amendments to the sectional title regulations. Tydskrif vir die Suid-Afrikaanse Reg, (3), pp. 555-562.

Van der Merwe, C.G. (2010). Establishment of parking bays in a sectional title scheme in favour of neighbouring properties: Review of the recent amendments to the sectional title regulations. Tydskrif vir die Suid-Afrikaanse Reg, (3), pp. 623-626.

Wegner, T. (2007). Applied Business Statistics, $2^{\text {nd }}$ edition. Cape Town: Juta.

Woudberg, T. (1999). Basic Sectional Title Book One, $2^{\text {nd }}$ edition. Durban: Butterworths. 
DIE TOEPASLIKHEID VAN DEELTITELHEFFINGS IN SUID-AFRIKA 